\title{
IDENTIFIKASI NILAI PENDIDIKAN KARAKTER DALAM PELAKSANAAN KEGIATAN EKSTRAKURIKULER DRUMBBAND
}

\author{
Nurin Fitria Alfinanda ${ }^{1}$, M. Reyhan Florean ${ }^{2}$ \\ ${ }^{1,2}$ STKIP PGRI Tulungagung
}

\begin{abstract}
Character is a person personality. School has an important role in character education, which one is through drumbband extracurricular. Extracurriculer is a place where student can develop their talent and ability outside the academic field. Drumbband extracurricular also can be a place wherestudent can develop their creativity and media to character education. The purpose of this research to identify the character education values in drumbband extracurricular at $2^{\text {nd }}$ Kedungwaru elementary school. This research use qualitative method. The data collection in this research include observation, interviews, and documentation. The data analysis technic in this research are data reduction, data presentation, and conclusion. The data validity in this research checking by observation extension, increase perseverance, triangulation. The result is character value in drumbband extracurricular is tolerance, discipline, communicative, work hard, and responsibility.
\end{abstract}

Keyword: character, extracurricular, drumbband

\begin{abstract}
Abstrak: Karakter merupakan sifat, watak, akhlak maupun kepribadian diri seseorang. Sekolah memiliki peranan memiliki peranan yang penting dalam pendidikan karakter, salah satunya melalui kegiatan ekstrakurikuler drumbband. Ekstrakurikuler merupakan wadah untuk peserta didik mengembangkan bakat dan kemampuan diluar bidang akademik, ekstrakurikuler drumband dapat menjadi sarana mengembagkan kreatifitas dan media untuk mendidik nilai-nilai karakter yang terdapat dalam diri peserta didik. Penelitian ini bertujuan untuk mengetahui nilai-nilai pendidikan karakter yang terkandung dalam proses kegiatan eksrakurikuler drumband di SD Negeri 2 Kedungwaru tahun ajaran 2018/2019. Penelitian ini merupakan penelitian kualitatif. Teknik pengumpulan data yang dilakukan meliputi observasi, wawancara dan dokumentasi. Teknik analisis data yang dilakukan dalam penelitian ini yaitu reduksi data, penyajian data, dan penarikan kesimpulan. Teknik pengecekan keabsahan data yang digunakan yaitu dengan perpanjangan pengamatan, meningkatkan ketekunan, triangulasi. Adapun hasil penelitian ini adalah nilai-nilai karakter yang terdapat pada ekstrakurikuler durmbband yaitu toleransi, disiplin, bersahabat/komunikatif, kerja keras, dan tanggung jawab.
\end{abstract}

Kata Kunci: Ekstrakurikuler, Drumbband, Karakter

I STKIP PGRI Tulungagung, Email: nurinfitriaDI03国gmail.com

${ }^{2}$ STKIP PGRI Tulungagung, Email: mreyhanflorean国gmail.com 


\section{PENDAHULUAN}

Karakter merupakan sifat, watak, akhlak ataupun kepribadian diri seseorang yang sejak lahir telah ada. Setiap individu memiliki karakter yang berbeda, maka dari itu setiap individu terdapat karakter yang tidak sama. Menurut Scerenko (1997) yang dikutip Samani (2017, hlm. 42) karakter merupakan ciri-ciri yang membentuk dan membedakan cirri pribadi, cirri etis, dan kompleksitas mental dari seseorang.

Menurut Mustakim (2011, hlm. 29) sebagaimana arti karakter secara individual, karakter kolektif pun berarti sifat khas dan hakiki pada suatu komunitas, kelompok masyarakat, maupun bangsa tertentu. Jika dikaitakan dalam peradapan manusia, karakter terbentuk sejak proses sejarah sebagai sifat utama untuk pondasi budaya bagi masyarakat. Maka dari itu perlu adanya pendidikan sebagai suatu institusi yang berfungsi mengajarkan sifat utama yang menjadi ciri khusus dalam suatu masyarakat ke diri peserta didik, yang bertujuan agar peserta didik tumbuh menjadi manusia yang bermartabat sehingga dapat berkembang dalam budaya masyarakat.

Pendidikan karakter merupakan suatu keniscayaan dalam upaya menghadapi berbagai tantangan pergeseran karakter yang dihadapi saat ini. Pendidikan karakter bertujuan mengembangkan kemampuan seseorang untuk memberikan keputusan baik buruk, memelihara apa yang baik dan mewujudkan kebaikan itu dalam kehidupan sehari-hari dengan sepenuh hati.

Pendidikan karakter adalah satu kewajiban karena pendidikan tidak hanya mengharuskan peserta didik menjadi cerdas akademik saja melainkan suatu pendidikan mempunyai etika yang baik, sikap santun dan menghargai agar keberadaan peserta didik di masyarakat dapat bermakna dalam keberagaman kehidupan masyarakat. Menurut Komalasari \& Saripudin (2017, hlm.1) Pendidikan karakter bertujuan mengembangkan kemampuan seseorang untuk memberikan baik buruk, memelihara apa yang baik dan mewujudkan kebaikan itu dalam kehidupan sehari-hari dengan sepenuh hati. Sekolah memiliki peran khusus dalam penanaman nilai karakter. Dalam hal ini sekolah juga memiliki peran yang penting dalam pendidikan karakter. Pendidikan karakter di sekolah dapat dilakukan melalui kegiatan di luar jam pembelajaran salah satunya melalui ekstrakurikuler. Sekolah merupakan salah satu pendidikan utama bagi siswa dalam memperoleh ilmu pengetahuan, akan tetapi pada dasarnya bukan hanya ilmu pengetahuan yang didapat di sekolah.

Ekstrakurikuler merupakan wadah untuk peserta didik mengembangkan bakat dan kemampuan di luar bidang akademik Pentingnya ektrakurikuler disekolah adalah sebagai sarana pengembangan kreatifitas siswa dan potensi siswa sebagai media mendidik nilai-nilai karakter, karena ketika siswa mengikuti ekstrakurikuler mereka belajar bekerja sama dengan siswa lainnya atau berkelompok. Kegiatan ekstrakurikuler merupakan salah satu komponen pendidikan karakter secara micro di sekolah, disamping pembelajaran dan budaya sekolah.

Penelitian tentang nilai karakter sudah banyak dilakukan seperti Zahidin \& Santosa (2017) meneliti tentang penanaman nilai-nilai karakter melalui Hadroh dan manajemen pendidikan karakter peserta didik melalui kegiatan ekstrakurikuler pramuka. Namun belum ada yang meneliti tentang identifikasi pendidikan nilai karakter pada ekstrakurikuler drumbband.

\section{TINJUAN PUSTAKA Karakter}

Setiap manusia pasti mempunyai karakter yang berbeda-beda. Karakter menjadi kunci penilaian kualitas mental atau moral, kekuatan, nama atau reputasi. Akar dari semua tindakan yang jahat dan buruk terletak pada hilangnya karakter. Karakter dimaknai sebagai cara berfikir 
dan berprilaku yang khas tiap individu untuk hidup dan bekerja sama, baik dalam lingkup keluarga, masyarakat, bangsa dan Negara. Individu yang berkarakter baik adalah individu yang dapat membuat keputusan dan siap bertanggung jawabkan setiap akibat dari keputusan (Samani, M \& Harianto, 2017, hlm.41).

Orang yang berkarakter adalah orang yang berkepribadian, berprilaku, bersifat, bertabiat, atau berwatak tertentu, dan watak tersebut yang membedakan dirinya dengan orang lain (Suyadi, 2015, hlm. 5). Karakter dapat dibentuk melalui proses pendidikan karakter. Secara universal berbagai karakter dirumuskan sebagai nilai hidup bersama berdasarkan atas pilar : kedamaian (peace), menghargai (respect), kerja sama (cooperation), kebebasan (freedom), kehagiaan (happiness), kejujuran (honesty), kerendahan hati (humility), kasih sayang (love), tanggung jawab (responsibility), kesederhanaan (simplicity), toleransi (tolerance), dan persatuan (unity) (Samani \& Harianto 2017, hlm. 42-43).

Dari pengertian-pengertian diatas dapat disimpulkan bahwa karakter adalah ciri khas yang dimiliki seseorang mengenai akhlak, pikiran, sikap, dan perilaku tertentu. Karakter sendiri dapat dibagi menjadi dua yakni karakter buruk dan karakter baik. Contoh karakter buruk adalah kurangnya disiplin anak, sikap kurang menghargai, malas. Sedangkan contoh karakter baik adalah tanggung jawab, disiplin.

\section{Hakekat Pendidikan Karakter}

Pendidikan karakter adalah suatu sistem penanaman nilai-nilai karakter yang meliputi komponen pengetahuan, kesadaran atau kemauan, dan tindakan untuk melaksanakan nilai-nilai tersebut, baik terhadap Tuhan Yang Maha Esa, diri sndiri, sesama, lingkungan, maupun kebangsaan. Akan tetapi karena manusia hidup dalam lingkungan sosial dan budaya tertentu, maka perkembangan karakter individu seseorang hanya dapat dilakukan di dalam lingkungan sosial dan budaya yang bersangkutan.

Penilaian pendidikan karakter pada hakikatnya adalah evaluasi atas proses pembelajaran secara terus menerus dari individu untuk menghayati peran dan kebebasannya bersama dalam sebuah lingkungan sekolah demi pertumbuhan integritas moralnya sebagai manusia (Koesoema, 2010, hlm. 281). Tujuan dari pendidikan karakter adalah menumbuhkan individu yang mampu memahami nilainilai moral dan produktif ketika mereka masih anak-anak dan menggunakan kapasitas mereka untuk melakukan yang terbaik dan melakukan hal yang benar. Helmawati (2017, hlm. 21) menyatakan tujuan dari pendidikan karakter adalah untuk menjadikan manusia menjadi manusia seutuhnya, manusia yang beradab dan bermartabat. Dengan peneladanan dan pembiasaan efektif ditemukan di lingkungan sekolah yang memungkinkan semua peserta didik berpotensi mendemonstrasikannya untuk mencapai tujuan yang sangat baik dan penting.

Dari penjelasan tersebut dapat disimpulkan bahwa hakikat pendidikan karakter merupakan sebuah proses pembelajaran seorang individu yang dilakukan secara terus-menerus dimana dalam hal ini sekolah juga memiliki peranan yang penting dalam pelaksanaannya.

\section{Nilai-Nilai Karakter}

Nilai-nilai karakter tersebut dapat didiskripsikan dalam tabel sebagai berikut.

\begin{tabular}{|c|c|c|}
\hline No. & Nilai & Deskripsi \\
\hline 1 & Religius & $\begin{array}{l}\text { Sikap dan perilaku dalam } \\
\text { melaksanakan ajaran } \\
\text { agama yang dianutnya, } \\
\text { toleran terhadap } \\
\text { pelaksanaan pelaksanaan } \\
\text { ibadah agama lain, dan } \\
\text { hidup rukun dengan } \\
\text { pemeluk agama lain. }\end{array}$ \\
\hline 2 & Jujur & $\begin{array}{lr}\text { Perilaku } & \text { yang } \\
\text { dilaksankan pada upaya } \\
\text { menjadikan dirinya } \\
\text { sebagai orang yang } \\
\text { selalu dapat dipercaya }\end{array}$ \\
\hline
\end{tabular}




\begin{tabular}{|c|c|c|}
\hline & & $\begin{array}{l}\text { dalam perkataan, } \\
\text { tindakan, dan pekerjaan. }\end{array}$ \\
\hline 3 & Toleransi & $\begin{array}{l}\text { Sikap dan tindakan yang } \\
\text { menghargai perbedaan } \\
\text { agama, suku, etnis, } \\
\text { pendapat, sikap, dan } \\
\text { tindakan orang lain yang } \\
\text { berbeda dari dirinya. }\end{array}$ \\
\hline 4 & Disiplin & $\begin{array}{l}\text { Tindakan } \text { yang } \\
\text { menujukkan perilaku } \\
\text { tertib dan patuh pada } \\
\text { berbagai ketentuan dan } \\
\text { peraturan. }\end{array}$ \\
\hline 5 & $\begin{array}{l}\text { Kerja } \\
\text { Keras }\end{array}$ & $\begin{array}{lr}\text { Perilaku } & \text { yang } \\
\text { menunjukkan upaya } & \text { unguh-sungguh dalam } \\
\text { sungguh } & \text { berbagai } \\
\text { mengatasi bi dar } & \text { hambatan belajar dan } \\
\text { tugas, } & \text { serta } \\
\text { menyelesaikan tugas } & \text { dengan sebaik-baiknya. } \\
\end{array}$ \\
\hline 6 & Kreatif & $\begin{array}{l}\text { Berfikir dan melakukan } \\
\text { sesuatu untuk } \\
\text { menghasilkan cara atau } \\
\text { hasil baru dari sesuatu } \\
\text { yang telah dimiliki. }\end{array}$ \\
\hline 7 & Mandiri & $\begin{array}{l}\text { Sikap dan perilaku yang } \\
\text { tidak mudah tergantung } \\
\text { pada orang lain dalam } \\
\text { menyelesaikan tugas- } \\
\text { tugas. }\end{array}$ \\
\hline 8 & Demokratis & $\begin{array}{l}\text { Cara berfikir, bersikap, } \\
\text { dan bertindak yang } \\
\text { menilai sama hak dan } \\
\text { kewajiban dirinya dan } \\
\text { orang lain. }\end{array}$ \\
\hline 9 & $\begin{array}{l}\text { Rasa Ingin } \\
\text { Tahu }\end{array}$ & $\begin{array}{lr}\text { Sikap dan tindakan yang } \\
\text { selalu berupaya } \\
\text { mengetahui } & \text { lebih } \\
\text { mendalam dan } & \text { meluas } \\
\text { dari sesuatu } & \text { yang } \\
\text { dipelajarinya, } & \text { dilihat, } \\
\text { dan didengar. } & \end{array}$ \\
\hline 10 & $\begin{array}{l}\text { Semangat } \\
\text { Kebangsaan }\end{array}$ & $\begin{array}{l}\text { Cara berfikir, bersikap, } \\
\text { dan berwawasan yang } \\
\text { menempatkan } \\
\text { kepentingan bangsa dan } \\
\text { Negara diatas } \\
\text { kepentingan diri dan } \\
\text { kelompok. }\end{array}$ \\
\hline 11 & $\begin{array}{l}\text { Cinta Tanah } \\
\text { Air }\end{array}$ & $\begin{array}{lr}\text { Cara berfikir, bersikap, } \\
\text { dan berbuat yang } \\
\text { menunjukkan kesetiaan, } \\
\text { kepedulian, ran }\end{array}$ \\
\hline
\end{tabular}

\begin{tabular}{|c|c|c|}
\hline & & $\begin{array}{l}\text { penghargaan yang tinggi } \\
\text { terhadap bahasa, } \\
\text { lingkungan fisik, sosial, } \\
\text { budaya, ekonomi, dan } \\
\text { politik bangsa. }\end{array}$ \\
\hline 12 & $\begin{array}{l}\text { Menghargai } \\
\text { Prestasi }\end{array}$ & $\begin{array}{lr}\text { Sikap dan tindakan yang } \\
\text { mendorong dirinya untuk } \\
\text { menghasilkan sesuai } \\
\text { yang berguna bagi } \\
\text { masyarakat, } \\
\text { mengakui, } \\
\text { menghormati } \\
\text { keberhasilan orang lain. }\end{array}$ \\
\hline 13 & $\begin{array}{l}\text { Bersahaba/ } \\
\text { Komunikatif }\end{array}$ & $\begin{array}{lr}\text { Tindakan } & \text { yang } \\
\text { memperhatikan rasa } \\
\text { senang berbicara, } \\
\text { bergaul, dan bekerja } \\
\text { sama dengan orang lain. }\end{array}$ \\
\hline 14 & Cinta Damai & $\begin{array}{l}\text { Sikap, perkataan, dan } \\
\text { tindakan yang } \\
\text { menyebabkan orang lain } \\
\text { merasa senang dan aman } \\
\text { atas kehadiran dirinya. }\end{array}$ \\
\hline 15 & $\begin{array}{l}\text { Gemar } \\
\text { membaca }\end{array}$ & $\begin{array}{l}\text { Kebiasaan menyediakan } \\
\text { waktu untuk membaca } \\
\text { berbagai bacaan yang } \\
\text { memberikan kebajikan } \\
\text { bagi dirinya. }\end{array}$ \\
\hline 16 & $\begin{array}{l}\text { Peduli } \\
\text { Lingkungan }\end{array}$ & $\begin{array}{l}\text { Sikap dan tindakan yang } \\
\text { selalu berupaya } \\
\text { mencegah kerusakan } \\
\text { pada lingkungan alam } \\
\text { disekitarnya, } \\
\text { mengembangkan dan } \\
\text { yang sudah terjadi. }\end{array}$ \\
\hline 17 & $\begin{array}{l}\text { Peduli } \\
\text { Sosial }\end{array}$ & $\begin{array}{l}\text { Sikap dan tindakan yang } \\
\text { selalu ingin member } \\
\text { bantuan pada orang lain } \\
\text { dan masyarakat yang } \\
\text { membutuhkan. }\end{array}$ \\
\hline 18 & $\begin{array}{l}\text { Tanggung } \\
\text { Jawab }\end{array}$ & $\begin{array}{lr}\text { Sikap dan } & \text { perilaku } \\
\text { seseorang } & \text { untuk } \\
\text { melaksankan tugas dan } & \text { kewajiban, yang } \\
\text { seharusnya dia lakukan, } \\
\text { terhadap diri sendiri, } \\
\text { masyarakat, lingkungan } \\
\text { (alam,sosial, } \\
\text { budaya), Negara dan } \\
\text { Tuhan Yang Maha Esa. }\end{array}$ \\
\hline
\end{tabular}

Sumber:Kementerian Pendidikan Nasional (2010) seperti dikutip (Komalasari \& Saripudin) pendidikan karakter. 
Nilai-nilai diatas tidak semua mutlak diterapkan, namun dapat disesuaikan dengan keinginnan, kebutuhan dan kemampuan satuan pendidik tertentu. Dalam implementasinya jumlah dan jenis karakter yang dipilih tentu akan berbeda antara satu daerah atau sekolah. Nilai-nilai yang akan dikembangkan tentunya disesuaikan dengan kepentingan sekolah itu sendiri.

\section{Ekstrakurikuler}

Kegiatan ekstrakurikuler adalah wahan pengembangan pribadi peserta didik melalui berbagai aktivitas, baik yang berkaitan langsung maupun tidak langsung dengan materi kurikulum. Tujuan pelaksanaan kegiatan ekstrakurikuler menurut Departemen Pendidikan dan Budayaan (1996) yang di kutip Komalasari \& Saripudin (2017, hlm.123) adalah untuk lebih memantapkan pembentukkan kepribadian dan untuk lebih mengaitkan antara pengetahuan yang diperoleh dalam program kurikulum dengan keadaan dan kebutuhan lingkungan.

Ekstrakurikuler dapat disimpulkan merupakan kegiatan yang dilaksanakan oleh peserta didik di luar jam pembelajaran intrakurikuler dan kokurikuler untuk mengembangkan potensi, bakat, minat, wawasan pengetahuan, sikap, kemauan/keterampilan, serta karakter siswa secara optimal yang di selenggarakan secara khusus oleh tenaga pendidikan yang berkemampuan dan berkewenangan di sekolah.

\section{Tujuan Ekstrakurikuler}

Suryosubroto (2009, hlm. 288) yang di kutip Komalasari \& Saripudin, (2017, hlm.122) Memaknai kegaiatn ekstrakurikuler sebagai berikut : a.) Kegiatan ekstrakurikuler harus dapat meningkatkan kemampuan siswa beraspek kognitif, afektif, dan psikomotorik; b.) Mengembangkan bakat dan minat siswa dalam upaya pembinaan pribadi menuju pembinaan manusia seutuhnya yang positif; c.) Dapat mengetahui, mengenal serta membedakan antara hubungan satu pelajaran dengan mata pelajaran lain.

Berdasarkan pengertian di atas tujuan ekstrakurikuler diatas dapat di simpulkan ekstrakurikuler dapat mengembangkan potensi peserta didik secara optimal dan terpadu yang meliputi bakat, minat dan kreativitas peserta didik. Dalam hal ini untuk memantapkan kpribadian peserta didik dalam mewujudkan menjadi pribadi yang berkarakter baik dan dapat mengembangkan bakat yang dimiliki.

\section{Manfaat Ekstrakurikuler}

Secara umum kegiatan ekstrakurikuler bermanfaat bagi siswa, guru, dan sekolah. Karena selain untuk menambah pengetahuan, wawasan, menyalurkan bakat dan minat siswa juga untuk popularitas sekolah sehingga menambah kualitas pendidikan dan proses belajar mengajar diseklolah tersebut. Selain itu manfaat kegiatan ini adalah wadah penyaluran hobi bagi peserta didik, mengembangkan kemampuan atau potensi siswa menjadi lebih percaya diri. Banyak manfaat yang diperoleh dari kegiatan ekstrakurikuler drumband antara lain membantu mengimplementasikan tujuan kegiatan intrakurikuler (Komalasari \& Saripudin, 2017, hlm.124).

Ekstrakurikuler ini mampu mendorong motivasi siswa terhadap mata pelajaran, siswa juga mampu mengembangkan nilai pendidikan karakter tanpa mereka sadari bahwa sedikit demi sedikit mereka telah mengamalkannya. Manfaat yang diperoleh dari kegiatan tersebut teutama dalam hubungan terhadap keefektifan dan keefesienan proses pembelajaran disekolah antara lain membantu mengimplementasikan tujuan kegiatan intrakurikuler. Adapun konribusi yang dapat disumbangkan kegiatan ekstrakurikuler bagi sekolah menurut Burrup (1967) yang dikutip oleh Komalasari \& Saripudin (2017, hlm.124) meliputi memunculkan kerja tim antara siswa, pengajar dan staf institusi, dapat 
memadukan berbagai bagian sekolah dan memberikan kesempatan yang luas.

Dari uraian diatas dapat disimpulkan bahwa manfaat dari ekstrakurikuler daapt menambah wawasan, pengetahuan, bakat dan minat, serta mampu mengembangkan nilai karakter peserta didik.

\section{Drumbband}

Drumbband merupakan salah satu ekstrakurikuler yang dilaksanakan di sekolah dasar. Menurut Sudrajat (2005) seperti dikutip Haryanggita (2015, hlm. 27) menyatakan bahwa defisini dari drumband merupakan suatu bentuk permainan musik dan olahraga yang terdiri dari beberapa orang personil untuk mengiringi langkah dalam berbaris atau berbaris dengan bermain musik. maka dari itu drumband sekelompok barisan orang yang memainkan aransemen lagu dengan menggunakan berbagai kombinasi alat musik secara bersama-sama, penampilan drumband merupakan kombinasi dari permainnan musik, serta baris-berbaris dari pemainnya.

Drumband biasanya memiliki anggota sekitar 50 orang ditingkat sekolah menengah keatas sedangkan untuk sekolah dasar kurang lebih hanya 25 orang peserta didik. Drumband adalah sekelompok barisan orang yang memainkan aransemen lagu dengan menggunakan berbagai kombinasi alat musik secara bersamasama, penampilan drumband merupakan kombinasi dari permainnan musik, serta baris-berbaris dari pemainnya. menurut Rakhamsyah (2018, hlm 41) drumband dilakukan secara kelompok dibutuhkan kerja sama yang baik antar siswa agar terjalin keselarasan dalam permainna drumband. Umumnya penampilan drumband dipimpin oleh satu atau dua orang komandan lapangan dan dilakukan di lapangan terbuka maupun lapangan tertutup dalam barisan yang membentuk formasi dengan pola yang senantiasa berubah-ubah sesuai dengan alur koreografi terhadap lagu yang dimainkan, dan diiringi dengan aksi tarian yang dilakukan oleh sejumlah pemain bendera.

Drumband biasanya di kategorikan menurut fungsi, jumlah anggota, komposisi dan jenis peralatan yang di gunakan, serta gaya atau corak penampilannya. Penampilan drumband pada mulanya adalah sebagai pengiring parade perayaan atau sebuah festival yang di lakukan di lapangan terbuka dalam bentuk barisan pola yang tetap dan kaku, serta hanya memainkan lagu-lagu mars.

Dinamika keseimbangan penampilan diperoleh hanya melalui individual yang dilakukan oleh mayoret. Namun saat ini permainnan musik drumband dapat dilakukan baik di lapangan terbuka ataupun tertutup sebagai pengisi acara dalam suatu perayaan, ataupun kejuaraan. Komposisi musik yang di mainkan drumband umumnya besifat lebih humoris dan tidak semata-mata memainkan lagu dalam bentuk mars. Macam-macam peralatan yang di gunakan lebih kompleks, formasi barisan yang lebih dinamis.

Drumband sekarang bukan hanya untuk perayaan, ataupun kejuaraan saja, unit ini telah masuk di dalam ekstrakurikuler pada tingkan pendidikan Sekolah Dasar (SD) dan Sekolah Menengah Pertama (SMP). Alat yang di gunakan di SD lebih sedikit dari mulai snare drum, bass drum, bellyra, symbal, trio dan perkus, mayoret, gitapati, dan bendera.

\section{METODOLOGI PENELITIAN}

Penelitian ini merupakan penelitian kualitatif yang bertujuan untuk menidentifikasi nilai-nilai pendidikan karakter pada ekstrakurikuler drumbband. Penelitian dilakukan di SDN 2 Kedungwaru, Tulungagung. Subjek dalam penelitian ini yaitu 25 anak yang mengikuti ekstrakurikuler drumbband terdiri dari kelas 3 sebanyak 8 siswa, kelas 4 sebanyak 10 siswa dan kelas 5 sebanyak 7 siswa. Penelitian ini dilakukan mulai bulan Februari 2019 sampai April 2019. 
Instrumen penelitian dalam penelitian ini yaitu pedoman observasi, pedoman wawancara, panduan dokumentasi.

Teknik pengumpulan data yang dilakukan yaitu observasi, wawancara dan dokumentasi. Observasi dilakukan untuk menggali informasi terkait pendidikan nilai karakter yang ada pada ekstrakurikuler drumbband. Observasi dilakukan dengan memberikan angket pertanyaan kepada peserta didik yang mengikuti ektrakurikuler drumbband. Wawancara dilakukan dengan informan seorang pelatih drumbband di SDN 2 Kedungwaru. Dokumentasi dalam penelitian ini merupakan foto selama kegiatan penelitian. Pengecekan keabsahan data pada penelitian ini menggunakan perpanjangan pengamatan, meningkatkan ketekunan, triangulasi teknik. Perpanjangan pengamatan dilakukan peneliti dengan kembali ke SD Negeri 2 Kedungwaru dan di fokuskan untuk mengecek kembali data yang telah di peroleh sebelumnya. Jika data yang di cek tidak berubah maka perpanjang pengamatan diakhiri. Meningkatkan ketekunan berarti peneliti melakukan pengamatan secara lebih cermat dan berkesinambungan. Sebagai bekal dalam meningkatkan ketekunan peneliti membaca berbagai hasil penelitian berupa jurnal atau buku yang terkait dengan temuan yang diteliti. Hal ini dilakukan agar wawancara peneliti semakin luas dan tajam sehingga dapat digunakan untuk memeriksa data yang ditemukan dalam penelitian.

Triangulasi teknik merupakan pengecekan data dari berbagai sumber dengan berbagai cara. Dalam penelitian ini data yang akan ditriangulasikan berasal dari hasil observasi, wawancara, dokumentasi. Melalui triangulasi teknik maka akan didapatkan suatu kesimpulan mengenai identifikasi nilai pendidikan karakter dalam pelaksanaan ekstrakurikuler drumband di lingkungan SD Negeri 2 Kedungwaru.

\section{HASIL PENELITIAN DAN PEMBAHASAN}

Hasil dari observasi menyatakan $68 \%$ peserta didik menyatakan sangat setuju bahwa sikap disiplin terdapat pada ekstrakurikuler drumband $28 \%$ menyatakan setuju dan $4 \%$ tidak setuju. Hal ini dapat diketahui dari peserta didik datang tepat waktu pada saat latihan ekstrakurikuler drumband. Selain itu sikap disiplin juga dapat dilihat dari peserta didik yang mengangkat alat mereka sendiri tanpa mengulur waktu saat melakukan persiapan. Berikut merupakan kutipan wawancara peneliti (P) dengan pelatih drumbband $(\mathrm{N})$.

P: "Apakah peserta didik dalam mengikuti ekstrakurikuler drumband selalu datang tepat waktu”? (item soal 2)

$N$ : 'Tidak mereka tidak pernah terlambat dalam ekstrakurikuler drumband bahkan mereka sudah mempersiapkan diri ketika saya belum datang, mereka sudah mempersiapkan alat musik mereka dan melakukan pemanasan terlebih dahulu, jadi ketika saya datang tinggal melanjutkan materi yang selanjutnya".

P: "bagaimana menurut pendapat bapak sikap apa yang mencerminkan prilaku peserta didik ini"?

$N$ : “ya, menurut saya sifat yang di miliki peserta didik mencerminkan sikap disiplin sebab mereka sudah memiliki rasa tanggung jawab”.

Berdasarkan kutipan wawancara tersebut dapat disimpulkan bahwa sikap disiplin peserta didik pada saat mengikuti ekstrakurikuler drumbband tercermin dari peserta didik mempersiapkan diri sebelum petalih datang dan melakukan pemanasan terlebih dahulu. Sikap ini sesuai dengan pendapat Komalasari \& Saripudin (2017, hlm.7) yang menyatakan pengertian dari disiplin adalah tindakan yang menunjukan perilaku tertib dan patuh pada berbagai ketentuan dan peraturan.

Pendidikan nilai karakter lain pada ekstrakurikuler drumbband yaitu toleransi. 
Hasil obsevasi menyatakan bahwa $48 \%$ peserta didik menyatakan sangat setuju bahwa sikap toleransi terdapat pada ekstrakurikuler drumband $48 \%$ menyatakan setuju dan $4 \%$ menyatakan tidak setuju. Hal ini dapat diketahui dari peserta didik yang membantu teman saat berlatih ekstrakurikuler drumband. Sikap toleransi juga dapat terlihat dari sikap dan tindakan siswa dalam berinteraksi dengan temannya, seperti disaat ada salah satu peserta didik yang masih belum hafal pelatih memberi arahan atau mengajarkan bagaimana yang benar dan yang lain mendengarkan atau bahkan ada yang salah memainkan lagu mereka membantu mengarahkan dan mengingatkan notasi lagu yang benar. Hasil obsevasi menyatakan bahwa $48 \%$, $48 \%$ menyatakan setuju dan $4 \%$ menyatakan tidak setuju bahwa peserta didik membantu teman mereka pada saat ada yang kesulitan. Berikut merupakan kutipan wawancara peneliti (P) dengan pelatih drumbband $(\mathrm{N})$.

$P$ :"bagaimana sikap toleransi yang peserta didik lakukan saat berlatih drumband"?

$N$ :"ketika ada salah satu temen yang salah notasi maka semua alat musik akan berhenti dan si anak yang melakukan kesalahan membenahi kesalahannya semua memulai lagu dari awal lagi"

$P$ :" apakah mereka tidak protes jika ada anak yang melakukan kesalahan berulang kali? dan alat musik apa yang sering sekali mengalami kesalahan"?

$N$ :"'tidak karena anak-anak memaklummi bahwa menghafal itu ya sulit hampir semua pernah melakukan kesalahan jadi mereka ya tidak pernah mempermasalahan teman yang salah notasi karena itu hal biasa dalam drumband. Yang paling sering salah notasi itu bellera karena notasi yang dihafalkan mereka cukup banyak".
Berdasarkan kutipan wawancara tersebut dapat disimpulkan bahwa sikap toleransi peserta didik pada saat mengikuti ekstrakurikuler drumbband tercermin dari peserta didik memaklumi jika ada temannya yang salah dalam mengikuti kegiatan atau melakukan kesalahan dalam memainkan alat musik. Sikap ini sesuai dengan pendapat Komalasari \& Saripudin (2017, hlm. 7) yang menyatakan pengertian dari toleransi adalah sikap dan tindakan yang menghargai perbedaan agama, suku, etnis, pendapat, sikap, dan tindakan orang lain yang berbeda dari dirinya.

Di dalam ekstrakurikuler juga terdapat sikap bersahabat/komunikasi. Komunikasi dalam ekstrakurikuler drumbband merupakan hal yang penting dalam membangun kekompakan dan kelancaran pada saat berlatih. Komunikasi ini juga dapat terlihat dari sikap peserta didik yang melakukan diskusi ketika pelatih memberikan lagu baru dan menghafalkan notasi tersebut secara bersama-sama. Hasil obsevasi menyatakan bahwa $44 \%$ peserta didik menyatakan sangat setuju bahwa sikap bersahabat/komunikasi terdapat pada ekstrakurikuler drumband 52\% menyatakan setuju dan 4\% menyatakan tidak setuju. Berikut merupakan kutipan wawancara peneliti (P) dengan pelatih drumbband $(\mathrm{N})$.

P: "apakah dalam kegiatan ekstrakurikuler drumband peserta didik mampu berkomunikasi dengan baik seperti dengan temannya atau bahkan dengan anda pak"?

$N$ :"iya mereka dalam kegiatan harus selalu berkomunikasi ketika mereka mengalami kesulitan mereka harus berani bertanya setidaknya dengna satu kolompok alat musik dan jika teman tidak bisa membantu maka meminta diajarkan oleh pelatih jika mengalami kesulitan tidak boleh malu-malu untuk bertanya". 
$P$ : "apakah dalam latihan ini sangat di butuhkan kerjasama antara peserta didik satu dengan yang lain"?

$N$ :"tentu saja sangat di butuhkan, karena dalam ekstrakurikuler drumband sangat berkaitan antara pemukul bellera, snardrum, bassdrum, simbal harus berirama dan berkesinambungan jadi sangat di butuhkan kekompakan dan konsentrasi peserta didik".

Berdasarkan kutipan wawancara tersebut dapat disimpulkan bahwa sikap komunikasi peserta didik pada saat mengikuti ekstrakurikuler drumbband tercermin dari peserta didik berani bertanya baik kepada pelatih maupun kepada teman pada saat mengalami kesulitan. Sikap ini sesuai dengan pendapat Komalasari \& Saripudin $(2017$, hlm.7) yang menyatakan pengertian dari bersahabat/komunikasi adalah tindakan yang memperhatikan rasa senang berbicara, bergaul, dan bekerja sama dengan orang lain.

Ketika peserta didik berlatih sangatlah menunjukkan sikap sungguhsungguh dalam mengatasi berbagai hambatan seperti harus menghafal notasi lagu dalam proses latihan drumband. Peserta didik berlatih dengan keras untuk menghafal lagu yang mereka mainkan agar menjadi lagu yang bagus dan sempurna untuk di dengar. Hasil obsevasi menyatakan bahwa $56 \%$ peserta didik menyatakan sangat setuju bahwa sikap kerja keras terdapat pada ekstrakurikuler drumband $28 \%$ menyatakan setuju dan $5 \%$ menyatakan tidak setuju. Hal ini dapat diketahui dari peserta didik yang bersungguh-sungguh menghafalkan notasi dalam bermain alat musik drumband. Berikut merupakan kutipan wawancara peneliti $(\mathrm{P})$ dengan pelatih drumbband $(\mathrm{N})$. $P$ : "apakah dalam latihan peserta didik selalu berusaha untuk selalu berlatih"?

$N$ :"iya, apa lagi peserta didik yang memegang belyra harus ekstra untuk menghafal notasi lagu karena yang biasanya paling sulit dan rumit ya belyra".

$P$ : "bagaimana cara bapak agar peseta didik tidak mudah putus asa jika belum menghafal"?

$N$ : "ya saya akan mengulang-ulang lagu tersebut dan bahkan jika ada anak yang sulit untuk menghafal notasi maka alat musik mereka bida mereka bawang pulang agar setiap saat dapat berlatih hingga lama kelamaan akan hafal, biasanya kalau alat di bawa pulang paling lama waktu 4 hari peserta didik langsung bisa menghafal".

Berdasarkan kutipan wawancara tersebut dapat disimpulkan bahwa sikap kerja keras peserta didik pada saat mengikuti ekstrakurikuler drumbband tercermin dari peserta didik mau mengulangi latihan dan mau mencoba kembali jika mereka masih menemui kesulitan seperti belum menghafal notasi lagu. Sikap ini sesaui dengan pendapat Komalasari \& Saripudin (2017, hlm. 7) yang menyatakan pengertian dari kerja keras yang menyatakan pengertian kerja keras adalah perilaku yang menujukan upaya sungguh-sungguh dalam mengatasi berbagai hambatan belajar dan tugas, serta menyelesaikan tugas degan sebaikbaiknya.

Peserta didik ketika akan berlatih, semua mengambil alat yang mereka pegang sehari-hari sewaktu berlatih begitu juga pada saat mengembalikan alat, peserta didik mengembalikan alat mereka sendiri- sendiri dengan rapi. Begitu juga pada saat pentas biasanya peserta didik juga meminjam baju dari sekolah dan pada saat mengembalikan juga dalam keadaan tertata rapi dan dikembalikan pada rak yang sudah di siapkan. Hasil obsevasi menyatakan bahwa $44 \%$ peserta didik menyatakan sangat setuju bahwa sikap tanggung jawab terdapat pada ekstrakurikuler drumband $40 \%$ menyatakan setuju dan $16 \%$ menyatakan tidak setuju. Hal ini dapat diketahui dari 
peserta didik yang mengembalikan alat pada tempatnya stelah berlatih ekstrakurkuler drumband. Berikut merupakan kutipan wawancara peneliti $(\mathrm{P})$ dengan pelatih drumbband $(\mathrm{N})$.

$P$ :" apakah dalam kegiatan ini peserta didik mencerminkan sikap tanggung jawab"? (item soal 9)

$N$ :"iyaa bisa dikatakan dalam kegiatan ini peserta didik bisa di katakan bertanggung jawab, semua yang di lakukan peserta didik dalam kegiatan ekstrakurikuler dibutuhkan sikap yang tanggung jawab, toleransi, disiplin, komunikasi, kerja keras".

Berdasarkan kutipan wawancara tersebut dapat disimpulkan bahwa sikap tanggung jawab dilakukan peserta didik dari awal latihan sampai akhir. Sikap ini sesuai dengan pendapat Komalasari \& Saripudin (2017, hlm.7) yang menyatakan pengertian dari tanggung jawab adalah sikap dan perilaku seseoarang untuk melaksanakan tugas dan kewajiban, yang seharunya dia lakukan terhadap diri sendiri, masyarakat, lingkungan (alam, sosial, dan budaya), Negara dan Tuhan Yang Maha Esa.

\section{KESIMPULAN}

Pendidikan karakter bukan hanya sekedar mengajarkan mana yang benar dan mana yang salah, dalam dunia pendidikan karakter terdapat 18 karakter yang akan di tanamankan di peserta didik. dari 18 nilai karakter tersebut akan diimplementasikan dalam diri peserta didik sebagai upaya membangun karakter bangsa. Nilai-nilai karakter 18 tersebut tidak semua mutlak diterapkan namun dapat disesuaikan dengan keinginan, kebutuhan dan kemampuan satuan pendidikan tertentu.

$$
\text { Nilai-nilai karakter yang }
$$
terkandung pada kegiatan ekstrakurikuler drumband di SD Negeri 2 Kedungwaru yaitu Toleransi, Disiplin, Bersahabat/Komunikatif, Kerja Keras, Tanggung Jawab. Nilai-nilai tersebut tercermin dalam kebiasaan peserta didik pada saat melaksanaan kegiatan ekstrakurikuler drumband.

Setelah peneliti melakukan penelitian terhadap kegiatan latihan drumband guna mengetahui nilai-nilai karakter yang ada, maka penelitian ini diharapkan berguna sebagai bahan masukan kepada kepala sekolah, guru maupun staf, masyarakat sekolah dalam lingkungan sekolah untuk lebih meningkatkan nilai karakter kegiatan ekstrakurikuler drumband serta hasil penelitain ini dapat dijadikan bahan referensi atau kajian pustaka untuk penelitian selanjutnya yang berhubungan dengan nilai-nilai kaakter yang ada dalam kegiatan ekstrakurikuler drumband yaitu, Toleransi, Disiplin, Bersahabat/ Komunikasi, Kerja Keras, Tanggung jawab.

\section{DAFTAR PUSTAKA}

Haryanggita, A. K. (2015). Pembelajaran Ekstrakurikuler Drumband di Madrasah Tsanawiyah Negeri Kedunggalan Ngawi. Pendidikan Seni Drama Tari Musik Fakultas Bahasa dan Seni. Universitas Negeri Surabaya.

Helmawati. (2017). Pendidikan Karakter. Bandung : PT. Remaja Rosdakarya Offset.

Komalasari, K \& Saripudin D. (2017). Pendidikan Karakter. Bandung: PT. Refika Aditama

Komalasari \& Saripudin. (2017). Pendidikan karakter : konsep dan aplikasi living values educattion. Bandung. PT Refika Aditama.

Koesoema, D (2010). Pendidikan Karakter. Jakarta : Grasindo.

Mustakim, K. (2017). Integrasi Nilai-Nilai

Karakter Dalam Pembelajaran Mata Kuliah Psikologi Pendidikan. Fakultaslas Keguruan dan Ilmu Pendidikan Universitas Islam Nusantara Bandung.

Rakhamsyah, R. (2018). Pengembangan Karakter Siswa Melalui Ekstrakurikuler Drum Band Di Sd 
Negeri Tanjungtirto 1 Berbah

Sleman. Yogyakarta: Jurnal

Pendidikan Musik Volume 7,

Nomor 1, Tahun 2018 (Page 2. 42)

Samani, M. \& Harianto. (2017).

Pendidikan Karakter. Bandung:

PT. Remaja Rosdakarya Offset.

Suyadi. (2015). Strategi pembelajaran pendidikan karakter. Bandung. PT remaja rosdakarya

Zahidin, A. \& Santosa. S .(2017).

Penananaman Nilai- Nilai

Karakter Melalui Ekstrakurikuler

Hadroh di MI Ma'aruf Giriloyo

Imogiri Bantul. Universitas Islam

Negeri Sunan Kalijaga Yogyakarta. 